\title{
Caesarean section in a tertiary care centre
}

\author{
Rina V. Patel, Divyanshi J. Shani*, Parul T. Shah, Dipali Pandey
}

Department of Obstetrics and Gynecology, SVP Hospital and NHL Medical College, Ahmedabad, Gujarat, India

Received: 29 May 2020

Accepted: 06 July 2020

\section{*Correspondence:}

Dr. Divyanshi J. Shani,

E-mail: divyanshishani@yahoo.com

Copyright: ( ) the author(s), publisher and licensee Medip Academy. This is an open-access article distributed under the terms of the Creative Commons Attribution Non-Commercial License, which permits unrestricted non-commercial use, distribution, and reproduction in any medium, provided the original work is properly cited.

\begin{abstract}
Background: Caesarean section constitutes a major surgical procedure characterized with morbidity even if it is performed a planned procedure. Postoperative infection in obstetrics continues to affect the practice of every surgeon. Infection can cause an increase in patient's stay in the hospital, create discomfort, cause disfigurement and lead to morbidities to the patient. Thus, preventive measures need to be constantly evaluated and updated and hence authors have to study and analyse prevalence of postoperative infectious morbidities.

Methods: The study was conducted in an Urban Based Medical College Hospital in Ahmedabad. It was a retrospective cross-sectional study of 50 cases of patients who suffered infectious complications post caesarean from $1^{\text {st }}$ March 2019 to $31^{\text {st }}$ March 2020.

Results: The prevalence rate of surgical site infection in my study is $5.9 \%$ whereas of post-operative puerperal sepsis is $0.6 \%$, of post-operative urinary tract infection is $1.09 \%$, of post-operative breast abnormalities is $0.16 \%$. The most common infectious morbidity amongst all was surgical site infection (surgical site) infection and its prevalence was $5.9 \%$.

Conclusions: The development of post-operative infection is an important event that can be prevented by taking proper precautions and following prescribed guidelines. There should be specific use of antibiotics in the postoperative period. In the event of early signs of sepsis antibiotics should be administered properly as per culture sensitivity report. The decrease in infection rate also indirectly reduce the health costs involved in treating them post operatively.
\end{abstract}

Keywords: Breast abscess, Infectious morbidities, Surgical site infection, Urinary tract infection

\section{INTRODUCTION}

Caesarean section constitutes a major surgical procedure characterized with morbidity even if it is performed a planned procedure. Infection can cause an increase in patient's stay in the hospital, create discomfort, cause disfigurement and lead to failure of operation leading to morbidities and mortalities. Infection continues to consume a considerable portion of health care finances. Infection control is a major concern in health care in general but it is a particular important issue in the sterile environment of operating room where patients undergo surgical procedures and are at a significant risk of perioperative nosocomial infection.
Disinfection of surfaces in operating room, proper sterilization with effective methods, maintenance of positive pressure in operating room, temperature and humidity regulation are some of the important factors to prevent infection. Sterilization of instruments can be done by autoclaving, formaldehyde vapour chambers, glutaraldehyde solution or with newer technique, hydrogen peroxide plasma sterilizing system. (STERRAD system).

It is in this context that preventive measures need to be constantly evaluated and updated and hence authors have to study and analyse prevalence of postoperative infectious morbidities. Caesarean delivery is a major 
obstetrical surgical procedure aiming to save the lives of mothers and foetuses. ${ }^{1}$ The incidence of caesarean deliveries, both repeat and primary, has risen dramatically over the last few decades, with an estimated global number of 22.9 million caesarean deliveries in 2012. ${ }^{2,3}$ As a surgical procedure, caesarean delivery may be accompanied by a number of complications, surgical site infection (SSI) being one of them. The rate of SSI ranges from $3 \%$ to $15 \%$ worldwide. ${ }^{4-6}$ The variation in incidence may reflect differences in population characteristics and risk factors, perioperative practices, and the duration from the procedure until ascertainment. The risk for developing SSI has significantly decreased in the last three decades, mainly owing to improvements in hygiene conditions, antibiotic prophylaxis, sterile procedures, and other practices. ${ }^{7,8}$

\section{Strategies to prevent post caesarean infectious morbidities in LSCS}

- Shower with $4 \%$ chlorhexidine gluconate the night before surgery

- If necessary, clip rather than shave pubic hair

- Avoid unnecessary vaginal examinations in labour

- Avoid unnecessary instrumentation in labour

- Prepare the skin with antiseptic agent immediately prior to surgery

- Administer appropriate injectable antibiotics prophylaxis half an hour to hour before surgery

- Avoid manual removal or placenta and foetal membranes

- Avoid closure of skin with staples

- Maintain strict glycemic control in women with diabetes

- Consider early removal of bladder catheters postoperatively. ${ }^{9}$

\section{METHODS}

This was retrospective cross-sectional study (observational study) with total 50 patients. The Study was conducted in the department of obstetrics and gynecology in Urban based Medical College Hospital, Ahmedabad during the period of $1^{\text {st }}$ March 2019 to $31^{\text {st }}$ March 2020.

\section{Inclusion criteria}

- It included data from all patients who underwent A Cesarean section in Urban based Medical College Hospital, Ahmedabad and had a postoperative infectious morbidity.

\section{Exclusion criteria}

- It included data from all patients who underwent A Cesarean section in Urban based Medical College Hospital, Ahmedabad and had a postoperative infectious morbidity.
Every patient put to this study was given pre operatively Injection cefotaxime, was catheterized and pre-operative preparation such as betadine wash were given.

Patients having uncomplicated C-sections had their catheter kept for 24 hours.

All patients who underwent $\mathrm{C}$-sections with indication of Previous 2 or more LSCS had their skin sutured in vertical mattress manner.

And the ones with other indications had their skin sutured either as vertical mattress or in subcuticular manner.

The patients who suffered infectious complication were identified on the basis of their diagnostic criteria and their proformas were filled.

\section{There were various high-risk factors considered which were}

- Obesity

- Anemia

- Gestational hypertension

- Diabetes mellitus (WHO criteria)

- Chorioamnionitis (ACOG criteria)

- Poor ANC care

- Long term steroid use

- Excessive blood loss in surgery

- Long duration of surgery.

\section{List of infectious morbidities}

Surgical site infection

Case definition and diagnostic criteria:

The centre for disease control and prevention defines SSI as an infection occurring within 30 days from the operative procedure in the part of the body where the surgery took place with complaint of purulent discharge from the culture of which organisms are isolated. ${ }^{10}$

\section{Blood stream infections including puerperal sepsis}

\section{According to $\mathrm{WHO}:{ }^{11}$}

Puerperal sepsis was defined as infection of the genital tract occurring at any time between the onset of rupture of membranes or labour, and the $42^{\text {nd }}$ day postpartum in which two or more of the following are present:

- $\quad$ Fever (oral temperature $38.5^{\circ} \mathrm{C} / 101.3^{\circ} \mathrm{F}$ or higher on any occasion).

- Pelvic pain.

- Abnormal vaginal discharge, e.g. presence of pus.

- Abnormal smell/foul odour of discharge.

- Delay in the rate of reduction of the size of the uterus (involution). 


\section{Urinary tract infections}

The diagnosis of urinary tract infection requires the presence of urinary tract-specific symptoms in the setting of significant bacteriuria with a quantitative count of $\geq 105$ colony forming units of bacteria per millilitre (CFU/ml) in one urine specimen. ${ }^{12,13}$

\section{Pelvic infections including pelvic abscess}

Pelvic infection can be classified as a clinical syndrome resulting from the ascending spread of microorganisms from the vagina and endocervix to the endometrium, fallopian tubes, and/or contiguous structures in a female who has lower abdominal pain, cervical motion tenderness, adnexal tenderness and who has not been diagnosed with any cause.

In addition to the preceding criteria, at least one of the following findings must also be present:

- Temperature greater than $100.4^{\circ} \mathrm{F}$ (greater than $\left.38.0^{\circ} \mathrm{C}\right)$

- Leukocytosis greater than 10,000 white blood cells $/ \mathrm{mm}^{3}$

- Purulent material in the peritoneal cavity obtained by cordocentesis or laparoscopy

- Pelvic abscess or inflammatory complex detected by bimanual examination or by sonography

\section{Pneumonia}

According to CDC, case definition ${ }^{14-17}$

Health-care-associated pneumonia, can be diagnosed by fever, cough, and development of purulent sputum, in combination with radiologic evidence of a new or progressive pulmonary infiltrate, leucocytosis, a suggestive Gram's stain, and growth of bacteria in cultures of sputum, tracheal aspirate, pleural fluid, or blood.

\section{Mastitis\breast abscess}

Case definition and diagnostic criteria (January 2020 CDC surveillance definitions $)^{18}$

A breast abscess or mastitis must meet at least one of the following criteria:

- Patient has organism(s) identified from affected breast tissue or fluid

- Patient has a breast abscess or other evidence of infection on gross anatomic or histopathologic exam.

- Patient has fever $\left(>38.0^{\circ} \mathrm{C}\right)$ and local inflammation of the breast.

In each of Infectious morbidities, prevalence rate was calculated as follows.
Calculating rate

$=$ Total number of Patients who developed the Infectious Morbidit

$=\frac{\text { Total number of Patients who underwent Caesarean Section } \mathrm{i}}{\mathrm{T}}$ $\times 100$

\section{RESULTS}

Out of all infectious morbidities, $76 \%$ were due to surgical site infection, $14 \%$ were due to urinary tract infection, $8 \%$ were due to puerperal sepsis, $2 \%$ were due to breast abscess.

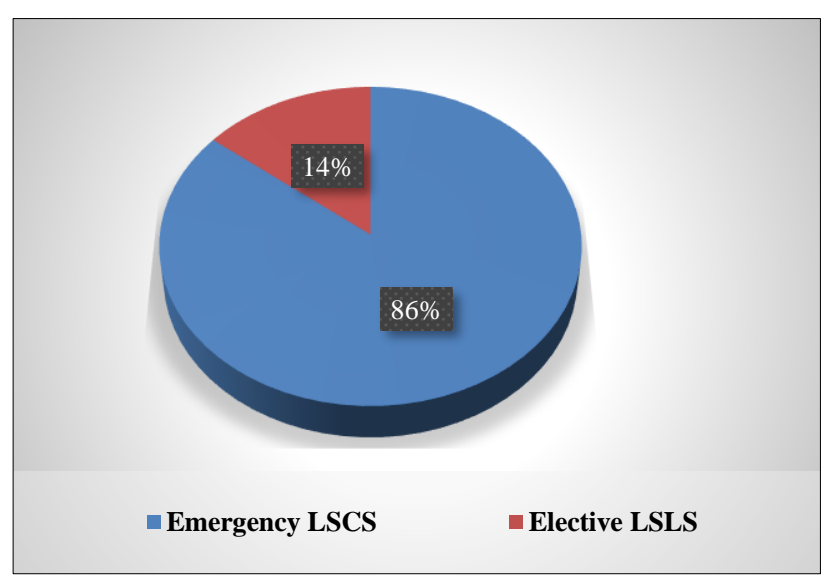

Figure 1: Type of LSCS and surgical site infection.

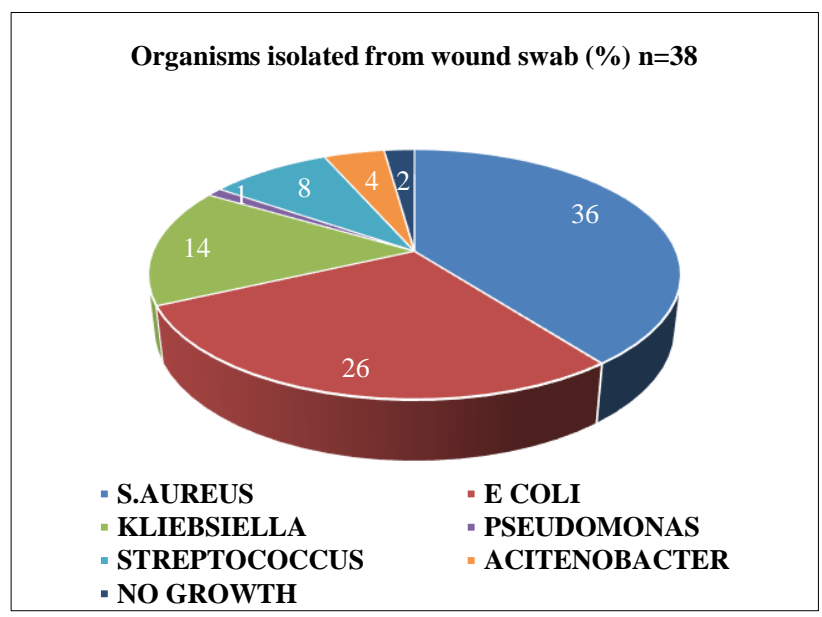

Figure 2: Organisms and surgical site infection.

Out of 50 patients who had infection, 42 were operated as emergency $\mathrm{C}$-section which is $84 \%$ and 8 were operated as elective C-section which is $16 \%$.

Out of the total 38 cases of wound infection, staph aureus was isolated from $36 \%$, E. Coli from $26 \%$, Kliebsiella from 14\%, Pseudomonas 1\% Streptococcus from $8 \%$ Acinetobacter from $4 \%$ and $2 \%$ had no growth.

Out of the total surgical site infection, $58 \%$ had Subcuticular Stitches while $42 \%$ had vertical mattress stitches. 
Table 1: Comparison amongst the infectious morbidities.

\begin{tabular}{|llll|} 
Infectious morbidities & Total no. of patients & $\begin{array}{l}\text { Out of all infectious morbidities } \\
(\mathbf{N = 5 0 )}\end{array}$ & $\begin{array}{l}\text { Out of all C-sections } \\
(\mathbf{N = 6 3 8 )}\end{array}$ \\
\hline Surgical site infection & 38 & $76 \%$ & $5.9 \%$ \\
\hline Urinary tract infection & 7 & $14 \%$ & $1.09 \%$ \\
\hline Puerperal sepsis & 4 & $8 \%$ & $0.6 \%$ \\
\hline Breast abscess & 1 & $2 \%$ & $0.16 \%$ \\
\hline
\end{tabular}

Table 2: Surgical site infection and type of skin closure.

\begin{tabular}{|lll|}
\begin{tabular}{|l} 
Type of skin \\
stitch
\end{tabular} & Number & $\begin{array}{l}\text { Percentage (from } \\
\text { total 38 surgical site } \\
\text { infection) }\end{array}$ \\
\hline Subcuticular & 22 & $58 \%$ \\
\hline Vertical mattress & 16 & $42 \%$ \\
\hline
\end{tabular}

Table 3: Duration of catheterization and UTI.

\begin{tabular}{|lll|}
\hline $\begin{array}{l}\text { No. of days } \\
\text { catheterized }\end{array}$ & $\begin{array}{l}\text { Number of patients } \\
\text { having UTI }(\mathbf{n}=7)\end{array}$ & Percentage \\
\hline$<24$ hours & 1 & $15 \%$ \\
\hline$>24$ hours & 6 & $85 \%$ \\
\hline
\end{tabular}

Table 4: Associated co-morbidities.

\begin{tabular}{|c|c|c|c|c|}
\hline ஓ & 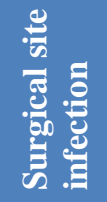 & $\bar{\beta}$ & 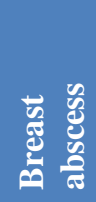 & 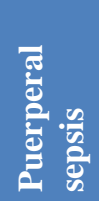 \\
\hline Diabetes & 12 & 3 & 1 & 2 \\
\hline Obesity & 8 & 1 & 0 & 0 \\
\hline Long surgery & 6 & 0 & 0 & 1 \\
\hline Anemia & 10 & 2 & 0 & 1 \\
\hline PIH & 2 & 1 & 0 & 0 \\
\hline
\end{tabular}

Out of the total patients with UTI, $85 \%$ had catheter for more than 24 hours and $15 \%$ had catheter for less than 24 hours.

The two most common co morbidities for surgical site infection were diabetes and anemia.

\section{DISCUSSION}

In various studies described above surgical site infection rates are comparable.

The prevalence rate of Surgical site infection in my study is $5.9 \%$ whereas of post-operative puerperal sepsis is $0.6 \%$, of post-operative urinary tract infection is $1.09 \%$, of post-operative breast abscess is $0.16 \%$.
Table 5: Rates of infection following caesarean delivery in different studies.

\begin{tabular}{|c|c|c|}
\hline Study & Type & $\begin{array}{l}\text { Surgical site } \\
\text { infection rate (\%) }\end{array}$ \\
\hline $\begin{array}{l}\text { Couto RC et } \\
\mathrm{al}^{20}\end{array}$ & $\begin{array}{l}\text { Prospective } \\
\text { observational }\end{array}$ & $32 / 951(3.4 \%)$ \\
\hline $\begin{array}{l}\text { Hebert PR et } \\
\mathrm{al}^{21}\end{array}$ & $\begin{array}{l}\text { Retrospective } \\
\text { cohort }\end{array}$ & $588 / 7441(7.9 \%)$ \\
\hline $\begin{array}{l}\text { Mah MW et } \\
\mathrm{al}^{22}\end{array}$ & $\begin{array}{l}\text { Prospective } \\
\text { surveillance }\end{array}$ & $20 / 735(2.7 \%)$ \\
\hline $\begin{array}{l}\text { Allen VM et } \\
\mathrm{al}^{23}\end{array}$ & $\begin{array}{l}\text { Retrospective } \\
\text { cohort }\end{array}$ & $11 / 721(1.5 \%)$ \\
\hline $\begin{array}{l}\text { Robinson } \\
\text { HE et al }{ }^{24}\end{array}$ & $\begin{array}{l}\text { Retrospective } \\
\text { population- } \\
\text { based cohort }\end{array}$ & $633 / 14,666(4.3 \%)$ \\
\hline $\begin{array}{l}\text { Olsen MA et } \\
\mathrm{al}^{19}\end{array}$ & $\begin{array}{l}\text { Retrospective } \\
\text { case control }\end{array}$ & $81 / 1695(4.8 \%)$ \\
\hline $\begin{array}{l}\text { Asch DA et } \\
\mathrm{al}^{25}\end{array}$ & Retrospective & $\begin{array}{l}65,103 / 1385,180 \\
(4.7 \%)\end{array}$ \\
\hline My study & $\begin{array}{l}\text { Retrospective } \\
\text { cross sectional }\end{array}$ & $38 / 638(5.9 \%)$ \\
\hline
\end{tabular}

The most common infectious morbidity amongst all was surgical site infection (surgical site) infection and its prevalence was $5.9 \%$. Which is comparable to other studies. $^{4-6}$

Surgical site infection is more common with subcuticular skin sutures as compared to vertical mattress.

Table 6: Comparative study of microorganisms isolated from positive wound culture. ${ }^{19}$

\begin{tabular}{|llll|}
\hline Organisms & $\begin{array}{l}\text { Sengupta } \\
\text { et al }\end{array}$ & $\begin{array}{l}\text { Arunkumari } \\
\text { et al }\end{array}$ & $\begin{array}{l}\text { My study } \\
\text { Pseudomonas }\end{array}$ \\
\hline Staph aureus & $7(21 \%)$ & $23(46 \%)$ & $2(5.3 \%)$ \\
\hline Klebsiella & $10(14.3 \%)$ & $15(30 \%)$ & $15(39.5 \%)$ \\
\hline
\end{tabular}

This difference in the values of different studies is due to the variation in sample size.

Staphylococcus aureus is the most common organism isolated from surgical site infection. 
Surgical site infections are more common in C-section done in emergency as compared to those done electively because of the fact that the patients operated on an emergency basis are usually referred as complicated or neglected cases with more high-risk factors. Moreover, in elective surgeries, factors such as operating conditions pre-operative preparations like betadine washing of the patient's body parts, antibiotics, associated co-morbid illness etc are better taken care of as compared to emergency surgeries. ${ }^{7,8}$

Prevalence of UTI is more common in patients in whom the catheter was kept for more than 24 hours.

Diabetes is the most common co-morbidity associated with surgical site infection.

Breast abscess is the least common infectious morbidity encountered post $\mathrm{C}$-section.

Post-operative infection remains a significant cause of maternal morbidity and mortality both developed and in developing countries. With a nowadays increase in incidence, cesarean delivery is the single most important risk factor for puerperal infection.

Limitation of study this study was a retrospective study, the patient skin preparation and pre and peri operative asepsis technique by doctor and other staff could not be evaluated properly. Also, number of pelvic examinations which has an important role in post-operative infections could not be evaluated in this retrospective study.

\section{CONCLUSION}

Proper skin preparation done before surgery reduces chances of SSI.

Caesarean sections should be performed electively whenever possible to reduce infectious morbidities.

High-risk patients should be given higher order antibiotics preoperatively.

There should be proper autoclaving and it should be taken care that set guidelines are strictly followed.

There should be proper fumigation periodically of all operation theatres.

The scrubbing technique protocols should be strictly followed by all, i.e., the nursing staff, the residents and the faculties.

Proper asepsis which includes not doing repeated Per vaginal examinations.

There should be judicious use of antibiotics in the postoperative period. In the event of early signs of sepsis antibiotics should be administered properly as per culture sensitivity report.

In case of co morbidities, expert opinion should be taken to correct co morbidities and reduce the infection rate.

If the above-mentioned measures are strictly followed, it would significantly reduce the infection rate in postoperative period.

The decrease in infection rate also indirectly reduce the health costs involved in treating them post operatively.

\section{ACKNOWLEDGMENTS}

Authors would like to thank all faculties, colleagues and operation theatre staff for their support.

Funding: No funding sources

Conflict of interest: None declared

Ethical approval: Not required

\section{REFERENCES}

1. Charoenboon C, Srisupundit K, Tongsong T. Rise in cesarean section rate over a 20 -year period in a public sector hospital in northern Thailand. Arch Gynecol Obstet. 2013;287(1):47-52.

2. Miller ES, Hahn K, Grobman WA. Consequences of a primary elective cesarean delivery across the reproductive life. Obstet Gynecol. 2013;121(4):78997.

3. Molina G, Weiser TG, Lipsitz SR, Esquivel MM, Uribe-Leitz T, Azad T, et al. Relationship between cesarean delivery rate and maternal and neonatal mortality. JAMA. 2015;314(21):2263-70.

4. Olsen MA, Butler AM, Willers DM, Devkota P, Gross GA, Fraser VJ. Risk factors for surgical site infection after low transverse cesarean section. Infect Control Hosp Epidemiol. 2008;29(6):477-84.

5. Schneid-Kofman N, Sheiner E, Levy A, Holcberg G. Risk factors for wound infection following cesarean deliveries. Int J Gynecol Obstet. 2005;90(1):10-5.

6. Opøien HK, Valbø A, Grinde-Andersen A, Walberg M. Post-cesarean surgical site infections according to CDC standards: rates and risk factors. A prospective cohort study. Acta Obstet Gynecol Scand. 2007;86(9):1097-102.

7. Gibbs RS. Clinical risk factors for puerperal infection. Obstet Gynecol. 1980;55(Suppl 5):S178S184.

8. Krieger Y, Walfisch A, Sheiner E. Surgical site infection following cesarean deliveries: trends and risk factors. J Matern Fetal Neonatal Med. 2016;705:1-5.

9. Taha O, Chappelle J. Optimal duration of urinary catheterization after cesarean delivery $[17 \mathrm{H}]$. Obstet Gynecol. 2018;131:91S.

10. Horan TC, Gaynes RP, Martone WJ, Jarvis WR. CDC definitions of nosocomial surgical site 
infections, 1992: a modification of CDC definitions of surgical wound infections. Infect Control Hosp Epidemiol. 1992;13(10):606-8.

11. Puerperal sepsis. Available at: https://www.nhp.gov.in/disease/gynaecology-andobstetrics/puerperal-sepsis. Accessed on $20^{\text {th }}$ February 2020.

12. Nicolle LE, Bradley S, Colgan R, Rice JC, Schaeffer A. Infectious diseases society of America guidelines for the diagnosis and treatment of asymptomatic bacteriuria in adults. Clin Infect Dis. 2005;40(5):64354.

13. Shea NL. Long-term-care-committee. Urinary tract infections in long-term-care facilities. Infect Control Hosp Epidemiol. 2001;22(3):167-75.

14. Bartlett JG, O'keefe P, Tally FP, Louie TJ, Gorbach SL. Bacteriology of hospital acquired pneumonia. Arch Intern Med. 1986;146(5):868-71.

15. Johanson WG, Jr., Pierce AK, Sanford JP, Thomas GD. Nosocomial respiratory infections with gramnegative bacilli. The significance of colonization of the respiratory tract. Ann Intern Med. 1972;77(5):701-6.

16. Andrews CP, Coalson JJ, Smith JD, Johanson WG. Diagnosis of nosocomial bacterial pneumonia in acute, diffuse lung injury. Chest. 1981;80(3):254-8.

17. Lowy FD, Carlisle PS, Adams A, Feiner C. The incidence of nosocomial pneumonia following urgent endotracheal intubation. Infect Control. 1987;8(6):245-8.

18. Horan TC, Andrus M, Dudeck MA. CDC/NHSN surveillance definition of health care-associated infection and criteria for specific types of infections in the acute care setting. Am J Infect Control. 2008;36(5):309-32.
19. Olsen MA, Butler AM, Willers DM, Devkota P, Gross GA, Fraser VJ. Risk factors for surgical site infection after low transverse cesarean section. Infect Control Hospital Epidemiol. 2008;29(6):477-84.

20. Couto RC, Pedrosa TM, Nogueira JM, Gomes DL, Neto MF, Rezende NA. Post-discharge surveillance and infection rates in obstetric patients. Int J Gynecol Obstet. 1998;61(3):227-31.

21. Hebert PR, Reed G, Entman SS, Mitchel EF, Berg C, Griffin MR. Serious maternal morbidity after childbirth: prolonged hospital stays and readmissions. Obstet Gynecol. 1999;94:942-7.

22. Mah MW, Pyper AM, Oni GA, Memish ZA. Impact of antibiotic prophylaxis on wound infection after cesarean section in a situation of expected higher risk. Am J Infect Control. 2001;29:85-8.

23. Allen VM, O'Connell CM, Liston RM, Baskett TF. Maternal morbidity associated with cesarean delivery without labor compared with spontaneous onset of labor at term. Obstet Gynecol. 2003;102:477-82.

24. Robinson HE, O'Connell CM, Joseph KS, McLeod NL. Maternal outcomes in pregnancies complicated by obesity. Obstet Gynecol. 2005;106:1357-64.

25. Asch DA, Nicholson S, Srinivas S, Herrin J, Epstein AJ, et al. Evaluating obstetrical residency programs using patient outcomes. JAMA. 2009;302:1277-83.

Cite this article as: Patel RV, Shani DJ, Shah PT, Pandey D. Caesarean section in a tertiary care centre. Int J Reprod Contracept Obstet Gynecol 2020;9:3106-11. 